\title{
PENYULUHAN MENGENAI USAHA KULINER DI MASA PANDEMI COVID-19 MELALUI DARING
}

\section{COUNCILING ABOUT CULINARY BUSINESS IN THE COVID-19 PANDEMIC THROUGH ONLINE MEDIA}

\author{
Irra Chrisyanti Dewi ${ }^{1)}$, Latifahtur Rahmah ${ }^{2)}$, Laela Nur Rokhmah ${ }^{3)}$, Nurul Azizah \\ Choiriyah $^{4)}$, Yohanna Prasetio ${ }^{5)}$ \\ ${ }^{1,2,4,5}$ Program Studi Seni Kuliner Akademi Kuliner dan Patiseri OTTIMMO Internasional \\ ${ }^{3}$ Program Studi Program Studi Teknologi Pangan, Politeknik Santo Paulus Surakarta \\ ${ }^{3}$ Email: nurul.azizah.choiriyah@gmail.com
}

Naskah diterima tanggal 05-11-2021, direvisi tanggal 29-10-2021, disetujui tanggal 26-11-2021

\begin{abstract}
Abstrak: Tujuan kegiatan pengabdian masyarakat ini yaitu memberikan pemahaman dan memberikan inspirasi kepada masyarakat mengenai usaha kuliner di masa pandemi. Kegiatan pengabdian masyarakat dilakukan secara daring menggunakan zoom dan youtube. Tahapan pengabdian dilakukan dengan pembuatan dan penyebaran flyer serta pembuatan materi. Tahap pelaksanaan dilakukan dengan penyampaian materi, demontrasi pembuatan corn almond pudding dan diskusi atau tanya jawab. Tahap akhir pengabdian yaitu evaluasi kegiatan pengabdian dengan pengisian kuisioner google form. Kegiatan pengabdian masyarakat berjalan lancar dengan dihadiri 122 orang peserta. Peserta antusias mengikuti setiap sesi acara pengabdian. Berdasarkan evaluasi kuisioner, diketahui bahwa hampir seluruh peserta mendapatkan inspirasi mengenai berwirausaha kuliner dan hampir seluruh peserta menjawab dengan benar pertanyaan yang berkenaan dengan usaha kuliner.
\end{abstract}

Kata Kunci: Coffee shop, Makanan sehat, Usaha kuliner, Pandemi Covid-19

Abstrack: The purpose of this community service activity is to provide understanding and inspiration to the public regarding culinary efforts during the pandemic. Community service activities are carried out online using zoom and youtube. The steps of this community services are preparation step, action step, and evaluation step. Preparation step was done by making and spreading the flyer. Action step was done by giving, explaining the knowledge about culinary business, demonstrating the making of corn almond pudding and discussing the topic given. Evaluation step was done by filling the questionnaire from the participant. Community service activities went well with 122 participants attended. Participants were enthusiastic about participating in each community service session. Based on the evaluation of the questionnaire, it is known that almost all participants received inspiration about culinary entrepreneurship and that almost all participants correctly answered questions relating to culinary business.

Keywords: Coffee shop, Healthy food, Culinary business, Covid-19 pandemic 


\section{PENDAHULUAN}

Secara psikologi, pandemi Covid-19 telah menyebarkan rasa panik, takut dan cemas secara berlebihan (Agung, 2020). Nugroho (2020) menyebutkan bahwa terlalu memantau kondisi Covid-19 dapat menyebabkan stress namun apabila terlalu acuh tak acuh juga dapat membawa risiko tertular virus ini. Boluarte Carbajal (2020) melaporkan bahwa pelayanan kesehatan yang tidak layak juga meningkatkan risiko penduduk mengalami stress. Masyarakat perlu memiliki pikiran dan bercara pandang positif pada situasi pandemi ini. Cara pandang positif misalnya di rumah saja tetap bisa bahagia, memiliki waktu yang lebih lama bersama anak dan lain sebagainya. Masyarakat perlu meningkatkan pengetahuan dan mengenali karakteristik dan perilaku virus Covid-19 ini.

Covid-19 juga membawa dampak besar pada sektor ekonomi (Burhanuddin dan Abdi, 2020) diantaranya ekspor, impor, perdagangan dan investasi (Nasution et al., 2020). Beberapa pekerja tenaga kesehatan yang takut untuk pergi ke kantor atau tempat kerja lebih memilih untuk resign (Boluarte Carbajal, 2020). Covid-19 juga membuat akses transportasi terbatas, tempat pariwisata, pusat perbelanjaan ditutup sehingga pendapatan menurun dan banyak 15,6\% karyawan diberhentikan dan 13,8\% diantaranya tidak diberikan upah pesangon (Ngadi et al., 2020).

Pandemi telah membuat kerugian besar. Masyarakat perlu mencari strategi baru agar tidak stress dan dapat bertahan hidup. Masyarakat juga perlu diberi pengetahuan agar memiliki pandangan baru untuk memiliki pekerjaan atau pendapatan baru di masa pandemi ini. Dengan adanya live zoom "Bangkit dari Masa Pandemi Covid-19 dengan Usaha Kuliner" ini diharapkan dapat meminimalisir risiko dan dampak pandemi Covid-19 pada sektor ekonomi. Tujuan kegiatan pengabdian masyarakat ini yaitu memberikan pemahaman dan memberikan inspirasi kepada masyarakat mengenai usaha kuliner di masa pandemi.

\section{METODE}

Kegiatan penyuluhan tentang usaha kuliner dilaksanakan pada tanggal 16 Oktober 2020 pukul 14.00 sampai dengan 16.15 WIB. Acara bertempat di Akademi Kuliner dan Patiseri OTTIMMO Internasional. Narasumber terdiri dari 4 
orang. Narasumber pertama yaitu Laela Nur Rokhmah memaparkan materi mengenai usaha kopi bubuk dan coffee shop selama pandemi Covid-19. Narasumber kedua yaitu dr Mega Selvia, MH, Med yang memaparkan mengenai Usaha kuliner dalam bentuk bistro di masa Pandemi Covid-19. Narasumber ketiga yaitu Latifahtur Rahmah yang memaparkan mengenai bisnis makanan sehat di masa Pandemi Covid-19. Narasumber keempat yaitu Yohanna Prasetio memberikan penyuluhan mengenai pembuatan corn almond pudding.

Penyelenggaraan kegiatan diawali dengan rapat penentuan judul dan waktu pelaksanaan penyuluhan. Tahap selanjutnya yaitu pembuatan flyer yang akan disebarkan melalui grup Whatsapp, instagram dan grup telegram. Kemudian dilakukan penyebaran flyer dan pendataan peserta yang mendaftar, pembuatan modul materi dan pada hari sebelum pelaksanaan dilakukan penyebaran link zoom dan link youtube kepada pendaftar kegiatan pengabdian masyarakat. Tahap pelaksanaan pengabdian ini terdiri dari penyampaian materi oleh keempat narasumber, tanya jawab mengenai materi penyuluhan dan pengisian daftar hadir. Tahap akhir kegiatan yaitu evaluasi kepada peserta pengabdian masyarakat dengan mengisi kuisioner yang dibagikan melalui google form.

\section{HASIL DAN PEMBAHASAN}

Pelaksanaan live zoom pengabdian masyarakat usaha kuliner di masa pandemi Covid-19 ditunjukkan pada Gambar 1. Gambar 1 menunjukkan foto sesi bersama pada saat kegiatan pengabdian masyarakat berlangsung. Kegiatan pengabdian masyarakat mengenai usaha kuliner diikuti oleh 122 peserta yang bergabung di media zoom dan youtube. Peserta berasal dari berbagai wilayah di Indonesia dan dari berbagai institusi pendidikan, institusi pemerintahan dan perusahaan swasta di Indonesia. Sebaran pekerjaan peserta sebagai berikut mahasiswa, dosen, pekerja swasta, Aparatur Sipil Negara (ASN), Guru, ahli gizi dan wiraswasta. 


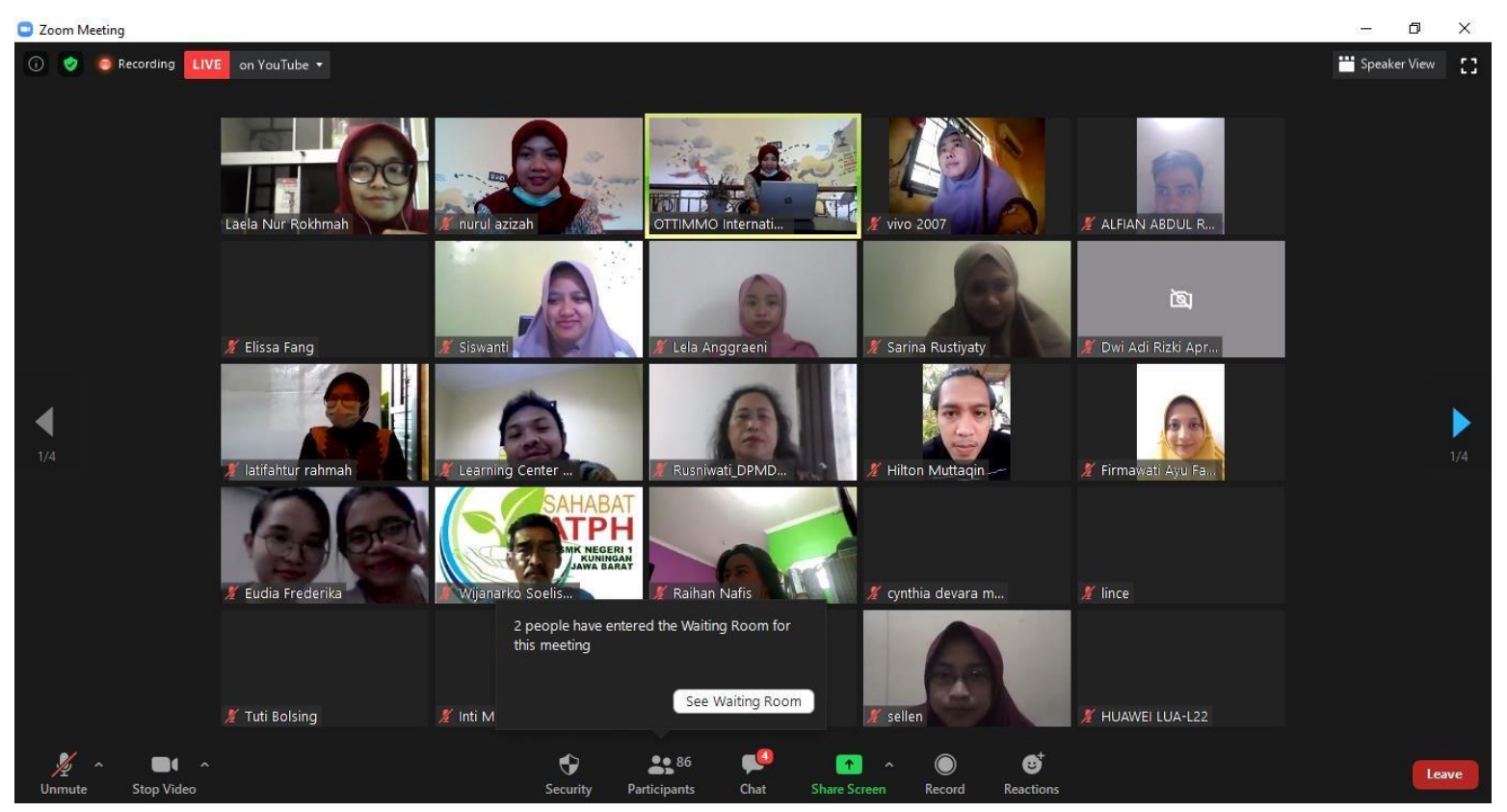

Gambar 1. Sesi foto bersama penyuluhan usaha kuliner di masa pandemic Covid-19

Penyampaian materi mengenai usaha kuliner diantaranya sebagai berikut dalam memulai bisnis kuliner maka pelaku usaha harus memiliki karakteristik pembeda dengan produk sejenis yang dikomersilkan. Teknik berjualan juga harus diperhatikan dalam bisnis kuliner. Teknik berjualan selama pandemi Covid-19 yang dapat dilakukan diantaranya berjualan secara online bekerja sama dengan jasa ojek online (Rohmah \& Syari, 2020), berjualan menggunakan media Instagram atau sosial media, menggunakan sistem pre-order makanan. Pelaku usaha juga perlu membangun kedekatan dengan pelanggan. Pada penjualan online, teknik food photography dapat dilakukan sebagai sarana periklanan. Hal yang perlu diperhatikan pada food photography yaitu komposisi, plating yang cantik dan penataan yang rapi (Cindi Adelia Putri, 2018).

Dalam berbisnis kuliner, agar dapat memperoleh profit maka perlu memperhatikan beberapa hal seperti meminimalisir pengeluaran yang tidak atau belum perlu, melakukan penjualan di berbagai saluran penjualan, melakukan analisa mengenai produk yang laris dijual (Widharta \& Sugiharto, 2013).

Pada masa pandemi Covid-19, banyak usaha kuliner mengalami penurunan pendapatan. Agar usaha kuliner tetap dapat bertahan pada kondisi sulit masa pandemi Covid-19, maka hal-hal yang perlu dilakukan diantaranya efisiensi bahan 


\section{INTEGRITAS : Jurnal Pengabdian}

Vol 5 No 2 Desember 2021

baku, menjaga higyene dan sanitasi tempat usaha kuliner, meningkatkan jaminan keamanan pangan produk kuliner (Bucak \& Yiğit, 2020), meningkatkan branding, pengiriman produk kuliner yang dipesan tepat waktu, melakukan inovasi produk, membuka alternatif jalur penjualan seperti menggunakan sistem drive thru dan tetap optimis bahwa penjualan tetap bertahan serta Covid-19 akan berlalu.

Dalam mengembangkan usaha coffee shop melibatkan berbagai pihak seperti petani, koperasi, processor, pedagang, roaster, kafe atau end user. BSN telah membuat klasifikasi mutu kopi yang berpengaruh terhadap harga kopi (Standar Nasional Indonesia, 2008). Pelaku usaha harus memiliki pengetahuan tentang kopi tidak asal melakukan penjualan.

Pada masa pandemi Covid-19, usaha kuliner yang banyak diminati masyarakat adalah makanan kesehatan. Chef dari Turki beryakinan bahwa ada perubahan menu di hotel selama Covid-19. Para chef hotel di Turki akan mengembangkan makanan gizi seimbang dan memenuhi gizi asupan untuk meningkatkan sistem imun (Bucak \& Yiğit, 2020). Makanan kesehatan yang dikembangkan di Indonesia dapat berupa salad yang terdiri dari sayur mayur yang dikemas dengan wrap edible, smoothies, frozen food, pudding dan minuman rempah-rempah.

Pada kegiatan pengabdian ini, juga dilakukan penyuluhan pembuatan pudding sehat "corn almond pudding". Penyuluhan pembuatan corn almond pudding ditunjukkan oleh Gambar 2. Bahan pembuatan corn almond pudding diantaranya $100 \mathrm{~g}$ jagung manis, $150 \mathrm{~g}$ almond direndam semalaman, $250 \mathrm{ml}$ air,50 $\mathrm{ml}$ susu rendah lemak, $1 \mathrm{gr}$ bubuk agar plain, biji vanili secukupnya, garam secukupnya dan $20 \mathrm{~g}$ gula pasir. Pembuatannya yaitu dengan menghaluskan almond dan jagung manis dengan ditambahkan air dan diblender kemudian pengambilan sari almond jagung yang telah disaring sebanyak $200 \mathrm{ml}$. Selanjutnya dilakukan perebusan sari almond jagung dan ditambahkan $50 \mathrm{ml}$ susu rendah lemak, 1 gr bubuk agar plain, biji vanili secukupnya, garam secukupnya dan $20 \mathrm{~g}$ gula pasir. Perebusan dilakukan hingga mendidih. Setelah itu dilakukan penuangan ke dalam cetakan. Setelah dingin maka corn pudding almond siap 


\section{INTEGRITAS : Jurnal Pengabdian}

Vol 5 No 2 Desember 2021

ISSN $2580-7978$ (cetak) ISSN 2615-0794 (online)

disajikan. Corn pudding almond merupakan salah satu alternatif makanan sehat karena mengandung tinggi serat.

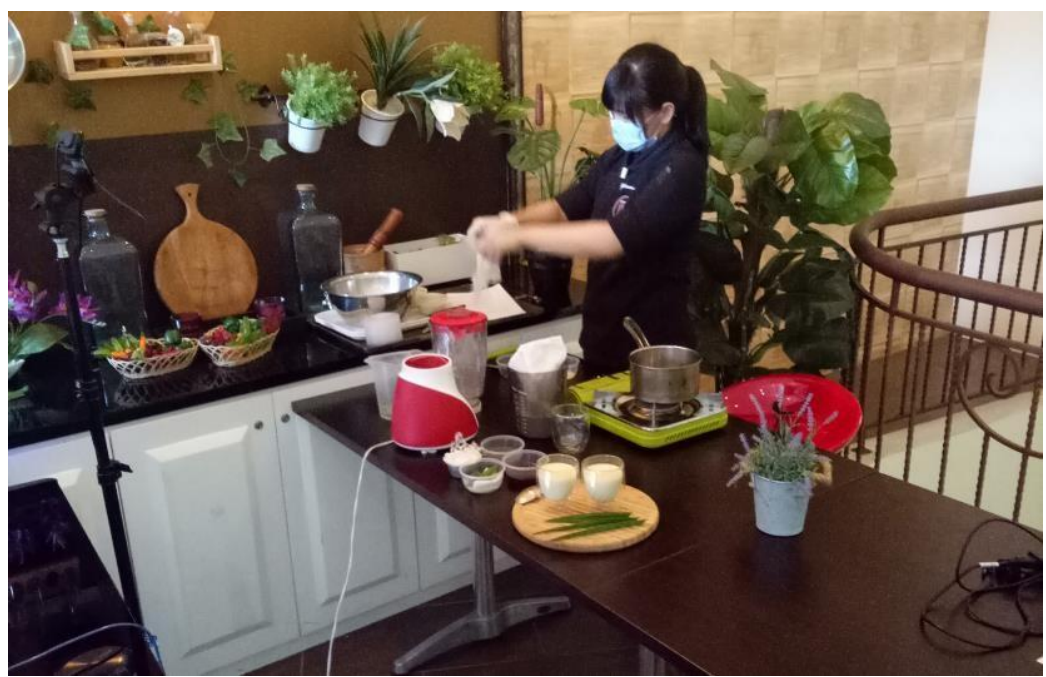

Gambar 2. Penyuluhan Pembuatan Corn Almond Pudding menggunakan media zoom dan youtube

Kegiatan pengabdian masyarakat berjalan dengan lancar tanpa mengalami kendala teknis. Peserta antusias dalam mengikuti jalannya pengabdian masyarakat pada setiap sesi acara. Banyaknya pertanyaan yang dilontarkan kepada narasumber menjadikan bukti bahwa peserta mengikuti acara dengan baik dan penuh semangat.

Tahap akhir pelaksanaan kegiatan pengabdian ini adalah evaluasi. Peserta mengisi evaluasi yang berisi kuisioner pertanyaan. Rekapitulasi pengisian kuisioner ditunjukkan oleh Tabel 1. Berdasarkan Tabel 1 dapat diketahui bahwa sebanyak 120 dari 122 peserta mendapatkan inspirasi mengenai berwirausaha kuliner setelah mengikuti kegiatan pengabdian masyarakat ini. Sebanyak 111 dari 122 peserta mampu menjawab dengan benar pertanyaan mengenai pemilihan bahan baku yang dapat mendukung keberlangsungan usaha kuliner di masa pandemi Covid-19. Sebanyak 121 dari 122 orang mampu menjawab dengan benar mengenai penjualan online mampu mendukung keberlangsungan usaha kuliner di masa pandemi Covid-19. Seluruh peserta yaitu sebanyak 122 orang mampu menjawab dengan benar pertanyaan mengenai hygiene dan sanitasi makanan serta protocol kesehatan untuk mendukung keberlangsungan usaha kuliner di masa 
INTEGRITAS : Jurnal Pengabdian

Vol 5 No 2 Desember 2021

ISSN 2580- 7978 (cetak) ISSN 2615-0794 (online)

pandemi Covid-19. Seluruh peserta juga mampu menjawab pertanyaan mengenai inovasi dalam bidang pangan/kuliner menghasilkan produk/menu dengan ciri khas tertentu, unik dan berbeda dengan bisnis makanan yang sudah ada

Tabel 1. Hasil evaluasi pelaksanaan pengabdian masyarakat dengan menggunakan google form

\begin{tabular}{|c|c|c|c|}
\hline No & Topik Pertanyaan & Jawaban & Jumlah \\
\hline 1 & $\begin{array}{l}\text { Pengabdian masyarakat memberikan inspirasi } \\
\text { kepada peserta untuk berwirausaha di bidang } \\
\text { kuliner }\end{array}$ & $\begin{array}{l}\text { Ya } \\
\text { Tidak }\end{array}$ & $\begin{array}{l}120 \\
2\end{array}$ \\
\hline 2 & $\begin{array}{l}\text { Pemilihan bahan baku dengan kualitas bagus dan } \\
\text { harga murah dapat mendukung usaha kuliner tetap } \\
\text { bertahan di masa pandemi Covid-19 }\end{array}$ & $\begin{array}{l}\text { Benar } \\
\text { Salah }\end{array}$ & $\begin{array}{l}11 \\
11\end{array}$ \\
\hline 3 & $\begin{array}{l}\text { Penjualan secara online penting diterapkan untuk } \\
\text { mendukung keberlangsungan usaha kuliner di } \\
\text { masa Pandemi }\end{array}$ & $\begin{array}{l}\text { Benar } \\
\text { Salah }\end{array}$ & $\begin{array}{l}121 \\
1\end{array}$ \\
\hline 4 & $\begin{array}{l}\text { Menjaga kebersihan makanan dan mematuhi } \\
\text { protokol kesehatan adalah kunci kualitas produk } \\
\text { yang dijual selama pandemi Covid-19 }\end{array}$ & $\begin{array}{l}\text { Benar } \\
\text { Salah }\end{array}$ & $\begin{array}{l}122 \\
0\end{array}$ \\
\hline 5 & $\begin{array}{l}\text { Inovasi dalam bidang pangan/kuliner } \\
\text { menghasilkan produk/menu dengan ciri khas } \\
\text { tertentu, unik dan berbeda dengan bisnis makanan } \\
\text { yang sudah ada }\end{array}$ & $\begin{array}{l}\text { Benar } \\
\text { Salah }\end{array}$ & $\begin{array}{l}122 \\
0\end{array}$ \\
\hline
\end{tabular}

\section{KESIMPULAN}

Pengabdian masyarakat ini diikuti oleh 122 orang peserta dari kalangan dosen, mahasiswa, pelaku usaha, aparatur sipil negara dan pekerja swasta. Pelaksanaan kegiatan pengabdian masyarakat dilakukan dengan penyampaian materi oleh narasumber, penyuluhan dengan demonstrasi langsung pembuatan corn almond pudding, tanya jawab antara peserta dengan narasumber serta evaluasi pelaksanaan kegiatan pengabdian masyarakat. Peserta mengikuti pengabdian masyarakat dengan tertib dan penuh antusias. Banyaknya pertanyaan yang ditujukan kepada narasumber membuktikan bahwa peserta mengikuti jalannya acara dengan penuh perhatian dan semangat. 
Berdasarkan pengisian kuisioner dapat diketahui bahwa hampir seluruh peserta mendapatkan inspirasi untuk berwirausaha kuliner, hampir seluruh peserta menjawab benar pertanyaan mengenai Pemilihan bahan baku dengan kualitas bagus dan harga murah dapat mendukung usaha kuliner tetap bertahan di masa pandemi Covid-19. Seluruh peserta mampu menjawab benar untuk pertanyaan mengenai penjualan secara online penting diterapkan untuk mendukung keberlangsungan usaha kuliner di masa pandemi, menjaga kebersihan makanan dan mematuhi protokol kesehatan adalah kunci kualitas produk yang dijual selama pandemi Covid-19 dan inovasi dalam bidang pangan/kuliner dapat menghasilkan produk/menu dengan ciri khas tertentu.

\section{DAFTAR PUSTAKA}

Agung, I.M. 2020. Memahami Pandemi COVID-19dalam Perspektif Psikologi Sosial. Psikobuletin: Buletin Ilmiah Psikologi Vol 1 (2): (68-84).

Boluarte Carbajal A, et al. Working conditions and emotional impact in health care workers during COVID-19 pandemic. J.healthc.qual.res.2020.https://doi.org/10.1016/j.jhqr.2020.08.002

Bucak, T., \& Yiğit, S. (2020). The future of the chef occupation and the food and beverage sector after the COVID-19 outbreak: Opinions of Turkish chefs. International Journal of Hospitality Management, 92(October 2020). https://doi.org/10.1016/j.ijhm.2020.102682

Burhanuddin, C.I. dan Abdi, M.N. 2020. ANCAMAN KRISIS EKONOMI GLOBAL DARI DAMPAK PENYEBARAN VIRUS CORONA (COVID-19). Akmen 17(1): 710-718.

Cindi Adelia Putri, E. (2018). Ingredients of Rendang Dalam Penciptaan Karya Food Photography. Jurnal, 1, 46-51.

Nasution, D.A.D., Erlina dan Muda, I. 2020. Dampak Covid-19 terhadap Perekonomian Indonesia. Jurnal Benefita 5 (2): 212-224.

Ngadi, Meilianna, R., Purba, Y.A. 2020. DAMPAK PANDEMI COVID-19 TERHADAP PHK DAN PENDAPATAN PEKERJADI INDONESIA. Jurnal Kependudukan Indonesia Juli 2020, pp: 43-48

Nugroho, A. 2020. Psikolog: Hadapi Pandemi Dengan Cara Pandang Positif. https://ugm.ac.id/id/berita/19807-psikolog-hadapi-pandemi-dengan-carapandang-positif diakses pada tanggal 01 Oktober 2020.

Rohmah, S. N., \& Syari, F. (2020). Adakah peluang bisnis di tengah kelesuan perekonomian akibat pandemi Corona virus Covid-19? 'ADALAH; Buletin Hukum \& Keadilan, 4(1), 63-74. 
INTEGRITAS : Jurnal Pengabdian

Vol 5 No 2 Desember 2021

ISSN 2580 - 7978 (cetak) ISSN 2615 - 0794 (online)

Standar Nasional Indonesia. (2008). Biji Kopi SNI 2907:2008. http://www.cctcid.com/wp-content/uploads/2018/08/SNI_29072008_Biji_Kopi-1.pdf

Widharta, W. P., \& Sugiharto, S. (2013). PENYUSUNAN STRATEGI DAN SISTEM PENJUALAN DALAM RANGKA MENINGKATKAN PENJUALAN TOKO DAMAI. JURNAL MANAJEMEN PEMASARAN PETRA, 2(1), 1-15. https://doi.org/10.4135/9781452229669.n3693 